\title{
Analysis of the American College of Surgeons National Surgical Quality Improvement Program ® (ACS NSQIP®) database to identify factors associated with postoperative mortality after elective non-cardiac surgery
}

Amit K. Malviya

All India Institute of Medical Sciences

Melanio Bruceta

Penn State Health Milton S Hershey Medical Center

Preet M. Singh

Washington University in Saint Louis

Anthony Bonavia

Penn State Health Milton S Hershey Medical Center

Kunal Karamchandani ( $\nabla$ drkunal_80@yahoo.com )

Penn State Health Milton S Hershey Medical Center https://orcid.org/0000-0003-3089-8088

Research article

Keywords: Postoperative mortality; ACS NSQIP区 risk calculator; prehabilitation; nutrition

Posted Date: July 14th, 2020

DOI: https://doi.org/10.21203/rs.3.rs-39590/v1

License: (c) (1) This work is licensed under a Creative Commons Attribution 4.0 International License. Read Full License 


\section{Abstract}

Background Various surgical risk assessment tools, including the American College of Surgeons National Surgical Quality Improvement Program ${ }^{\circledR}\left(\right.$ ACS NSQIP $\left.^{\circledR}\right)$ risk calculator have been devised to predict postoperative mortality. However, the role of individual factors on mortality is unclear. We sought to identify patient characteristics from the database that were associated with postoperative mortality in patients undergoing elective, non-cardiac surgery.

Methods Data from the ACS NSQIP ${ }^{\circledR}$ database at a tertiary care academic medical center was analyzed from January 2011 to September 2016. Relevant patient related variables were extracted from the database and univariable logistic regression was used to assess the association of each potential risk factor with 30-day mortality. A multivariable logistic regression model was then used to assess the adjusted effect of each potential risk factor on the outcome.

Results 5,254 database patient records were identified and among the analyzed variables, American Society of Anesthesiologists (ASA) physical status III and IV (odds ratio and 95\% Cl : $16.75[2.29,122.69]$ ), poor preoperative functional health status (Odds ratio and $95 \% \mathrm{Cl}: 38.52[2.46,604.12]$ ), and low serum albumin (Odds ratio and $95 \% \mathrm{Cl}: 3.76[1.35,10.44])$ were significant predictors of 30 -day postoperative mortality.

Conclusions In a comprehensive analysis of the ACS NSQIP ${ }^{\circledR}$ database, spreading across multiple surgical specialties, we found an association between ASA physical status, preoperative albumin levels, and functional health status with 30-day mortality after elective non-cardiac surgery.

\section{Background}

Despite significant advances in surgical and anesthesia care, postoperative morbidity and morbidity following elective, non-cardiac surgery ranges from $0.4-12 \%(1)$. Early detection of at-risk patients can help devise intervention strategies to optimize modifiable risk factors prior to surgery. Further, an estimation of the risk of postoperative complications and mortality can help guide risk-benefit discussions between patients and surgeons prior to elective surgery. As a consequence, many risk assessment tools have been developed with the goal of identifying those patients at high risk of perioperative complications (2).

The American College of Surgeons National Surgical Quality Improvement Program ${ }^{\circledR}$ (ACS NSQIP ${ }^{\circledR}$ ) is a nationally validated, risk-adjusted, and outcomes-based risk assessment tool (3). The database is comprised of de-identified patient information and tracks surgical outcomes with the goal of providing feedback to participating institutions.(4) The database contains preoperative and intraoperative variables which have been used to devise a surgical risk calculator (SRC).(5) The SRC has shown mixed results in predicting postoperative complications in different surgical populations $(6,7)$ and this discordance could, in part, be due to varying effect of the included predictors. The aim of this retrospective cohort study is to 
identify the role of individual contributors of the ACS NSQIP ${ }^{\circledR}$ SRC in impacting postoperative mortality in patients undergoing a wide array of non-cardiac surgical procedures.

\section{Methods}

\section{Data Source}

After approval by the Penn State College of Medicine Institutional Review Board (Study no: 7024, approval date: 03/28/2017), information on all elective non-cardiac surgical cases was obtained from the ACS NSQIP ${ }^{\circledR}$ database for the Penn State Milton S. Hershey Medical Center, from January 2011 through September 2016. We used the methodology previously described by Bruceta et al. (8) The ACS NSQIP ${ }^{\circledR}$ obtains its data from randomly assigned patients by rigorously trained and audited data abstractors. The database records hospital-reported preoperative and post-surgical outcomes for 30 days (4).

Demographic details, preoperative comorbidities, preoperative laboratory results and postoperative complications were extracted from the database and are detailed in supplementary table 1.

\section{Study Sample}

Patients who were older than 18 years, underwent elective inpatient non-cardiac surgery at Penn State Health Milton S. Hershey Medical Center and whose records were part of the hospital ACS NSQIP ${ }^{\circledR}$ database were included in the study.

\section{Statistical Analysis}

We applied the statistical approach previously described by Bruceta et al.(8) Specifically, the descriptive data are reported as frequencies and percentages for categorical variables and as means and standard deviations (SD) for continuous variables. Furthermore, continuous variables were assessed for normality by examining normal probability plots. Univariable logistic regression was used to assess the association of each potential risk factor with 30-day mortality after surgery. The effect size from each logistic regression model was quantified using the odds ratio (OR) and $95 \%$ confidence interval $(\mathrm{Cl})$. A multivariable logistic regression model was then used to assess the adjusted effects (i.e., the adjusted odds ratio) of each potential risk factor on the outcome. All hypothesis tests were two-sided and all statistical analyses were performed using $\mathrm{R}$, a software for statistical computing (R version 3.5.3).

\section{Results}

A total of 5254 patients were included in the analysis. A significant proportion of patients were young (65.3\%), however the majority of patients had an ASA status III or IV (65.8\%) and almost half of the patients were obese. The mean procedure duration was about 4 hours and $83 \%$ of patients had surgical duration less than 6 hours. The most common comorbidity in the study population was hypertension $(51.3 \%)$ and about $20 \%$ of the patients were active smokers. The mean hospital length of stay was 4.7 days, and $20 \%$ of the patients stayed in the hospital for a week or more. The overall 30 -day mortality in 
the study cohort was $0.6 \%$ (33 patients). Table 1 depicts the univariable and multivariable analysis for 30 day mortality. Cases with missing predefined covariates and variables without significant odds ratio were excluded from the multivariable logistic regression analyses. ASA physical status III and IV (OR and $95 \% \mathrm{Cl}: 16.75[2.29,122.69]$ ), poor preoperative functional health status (OR and $95 \% \mathrm{Cl}: 38.52[2.46$, $604.12]$ ), and low serum albumin (OR and $95 \% \mathrm{Cl}: 3.76[1.35,10.44])$ were identified as significant predictors of 30-day postoperative mortality in the multivariable model. Table 2 shows the percentage of cases with postoperative mortality specified by each surgical specialty. 
Table 1

Univariable and Multivariable Logistic Regression Analysis of NSQIP variables and association with postoperative mortality.

\begin{tabular}{|c|c|c|c|c|}
\hline Variable & $\mathrm{n}$ & $\begin{array}{l}\text { Postop death within } 30 \text { days } \\
\text { (\# of cases) }\end{array}$ & $\begin{array}{l}\text { Univariable } \\
\text { OR } \\
(95 \% \mathrm{Cl})\end{array}$ & $\begin{array}{l}\text { Multivariable } \\
\text { OR } \\
(95 \% \mathrm{Cl})\end{array}$ \\
\hline Total & 5254 & 33 & & \\
\hline \multicolumn{5}{|l|}{ Age (\%) } \\
\hline Mean Age (SD) & $\begin{array}{l}57.7 \pm \\
15.1\end{array}$ & & & \\
\hline$\leq 65$ & $\begin{array}{l}3432 \\
(65.3)\end{array}$ & 12 & 1 & 1 \\
\hline$>65$ & $\begin{array}{l}1822 \\
(34.7)\end{array}$ & 21 & $\begin{array}{l}1.06(1.03, \\
1.09)\end{array}$ & $1.01(0.98,1.06)$ \\
\hline \multicolumn{5}{|l|}{ Gender (\%) } \\
\hline Female & $\begin{array}{l}2524 \\
(48.0)\end{array}$ & 11 & 1 & \\
\hline Male & $\begin{array}{l}2730 \\
(52.0)\end{array}$ & 22 & $\begin{array}{l}1.86(0.90 \\
3.84)\end{array}$ & $1.68(0.65,4.31)$ \\
\hline \multicolumn{5}{|l|}{$\begin{array}{l}\text { Procedure } \\
\text { Duration (\%) }\end{array}$} \\
\hline $\begin{array}{l}\text { Mean Duration } \\
\text { (SD) }\end{array}$ & $\begin{array}{l}232.6 \pm \\
151.4\end{array}$ & & & \\
\hline$<6$ hours & $\begin{array}{l}4372 \\
(83.2)\end{array}$ & 17 & 1 & 1 \\
\hline
\end{tabular}

Number in parenthesis is the percentage of total cases pertaining to that group and variable.

Chosen references are indicated by number 1 . For preoperative diagnoses, a chosen reference is not having the diagnosis ex. no diabetes, non-smoker, no dyspnea, etc. This is not reported on the table. For preoperative laboratory results, a chosen reference is the normal value of the laboratory test (serum sodium 135-145 mEq/L, creatinine $<1.2 \mathrm{mg} / \mathrm{dl}$, albumin $>3.5 \mathrm{~g} / \mathrm{dl}$, Total bilirubin $<1.2 \mathrm{mg} / \mathrm{dl}$, hematocrit $>30$, and INR < 1.2). Normal values are not reported in the table.

Covariates for the multivariable logistic regression analysis include all of those with a statistically significant OR.

Abbreviations: ASA, American Society of Anesthesiology; ACS NSQIP, American College of Surgeons National Surgical Quality Improvement Program; OR, Odds Ratio; Cl, Confidence Interval; SD, Standard Deviation; BMI, Body Mass Index; IDDM, Insulin Dependent Diabetes Mellitus; NIDDM, Non-Insulin Dependent Diabetes Mellitus; FHS, Functional Health Status; COPD, Chronic Obstructive Pulmonary Disease; Med, Medication; HTN, Hypertension; INR, International Normalized Ratio

** BMI was not recorded for 9 patients 


\begin{tabular}{|c|c|c|c|c|}
\hline Variable & $\mathbf{n}$ & $\begin{array}{l}\text { Postop death within } 30 \text { days } \\
\text { (\# of cases) }\end{array}$ & $\begin{array}{l}\text { Univariable } \\
\text { OR } \\
(95 \% \mathrm{Cl})\end{array}$ & $\begin{array}{l}\text { Multivariable } \\
\text { OR } \\
(95 \% \mathrm{Cl})\end{array}$ \\
\hline$\geq 6$ hours & $\begin{array}{l}882 \\
(16.8)\end{array}$ & 16 & 1 & 1 \\
\hline \multicolumn{5}{|l|}{$\begin{array}{l}\text { ASA } \\
\text { Classification (\%) }\end{array}$} \\
\hline ASA I + II & $\begin{array}{l}1795 \\
(34.2)\end{array}$ & 1 & 1 & 1 \\
\hline ASA III + IV & $\begin{array}{l}3459 \\
(65.8)\end{array}$ & 32 & $\begin{array}{l}4.07(2.12 \\
7.83)\end{array}$ & $\begin{array}{l}16.75(2.29 \\
122.69)\end{array}$ \\
\hline Total & 5245 & & & \\
\hline BMI (\%) & & & $\begin{array}{l}1.03(0.96 \\
1.09)\end{array}$ & \\
\hline 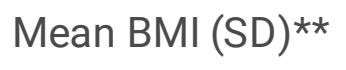 & $31.7 \pm 9.0$ & & & \\
\hline$<30$ & $\begin{array}{l}2651 \\
(50.5)\end{array}$ & 10 & 1 & 1 \\
\hline$\geq 30$ & $\begin{array}{l}2594 \\
(49.5)\end{array}$ & 13 & $\begin{array}{l}0.96(0.91 \\
1.00)\end{array}$ & $1.03(0.96,1.10)$ \\
\hline Total & 5254 & & & \\
\hline IDDM & $353(6.7)$ & 1 & $\begin{array}{l}0.51(0.07 \\
3.75)\end{array}$ & $0.31(0.04,2.60)$ \\
\hline NIDDM & $\begin{array}{l}599 \\
(11.4)\end{array}$ & 8 & $\begin{array}{l}2.41(1.08 \\
5.40)\end{array}$ & $2.00(0.71,5.65)$ \\
\hline
\end{tabular}

Number in parenthesis is the percentage of total cases pertaining to that group and variable.

Chosen references are indicated by number 1 . For preoperative diagnoses, a chosen reference is not having the diagnosis ex. no diabetes, non-smoker, no dyspnea, etc. This is not reported on the table. For preoperative laboratory results, a chosen reference is the normal value of the laboratory test (serum sodium 135-145 mEg/L, creatinine $<1.2 \mathrm{mg} / \mathrm{dl}$, albumin $>3.5 \mathrm{~g} / \mathrm{dl}$, Total bilirubin $<1.2 \mathrm{mg} / \mathrm{dl}$, hematocrit $>30$, and INR < 1.2). Normal values are not reported in the table.

Covariates for the multivariable logistic regression analysis include all of those with a statistically significant OR.

Abbreviations: ASA, American Society of Anesthesiology; ACS NSQIP, American College of Surgeons National Surgical Quality Improvement Program; OR, Odds Ratio; Cl, Confidence Interval; SD, Standard Deviation; BMI, Body Mass Index; IDDM, Insulin Dependent Diabetes Mellitus; NIDDM, Non-Insulin Dependent Diabetes Mellitus; FHS, Functional Health Status; COPD, Chronic Obstructive Pulmonary Disease; Med, Medication; HTN, Hypertension; INR, International Normalized Ratio

** BMI was not recorded for 9 patients 


\begin{tabular}{|c|c|c|c|c|}
\hline Variable & $\mathrm{n}$ & $\begin{array}{l}\text { Postop death within } 30 \text { days } \\
\text { (\# of cases) }\end{array}$ & $\begin{array}{l}\text { Univariable } \\
\text { OR } \\
(95 \% \mathrm{Cl})\end{array}$ & $\begin{array}{l}\text { Multivariable } \\
\text { OR } \\
(95 \% \mathrm{Cl})\end{array}$ \\
\hline Smoker & $\begin{array}{l}1021 \\
(19.4)\end{array}$ & 12 & $\begin{array}{l}2.39(1.17 \\
4.86)\end{array}$ & $2.27(0.82,6.32)$ \\
\hline $\begin{array}{l}\text { Presence of } \\
\text { Dyspnea }\end{array}$ & $\begin{array}{l}713 \\
(13.6)\end{array}$ & 8 & $\begin{array}{l}2.29(1.09, \\
4.83)\end{array}$ & $1.74(0.69,4.40)$ \\
\hline $\begin{array}{l}\text { FHS-Partial } \\
\text { Dependent }\end{array}$ & $69(1.3)$ & 2 & $\begin{array}{l}5.13(1.20 \\
21.88)\end{array}$ & $1.47(0.18,12.29)$ \\
\hline $\begin{array}{l}\text { FHS-Total } \\
\text { Dependent }\end{array}$ & $4(0.1)$ & 1 & $\begin{array}{l}57.23(5.79, \\
566)\end{array}$ & $\begin{array}{l}38.52(2.46, \\
604.12)\end{array}$ \\
\hline COPD & $314(6.0)$ & 6 & $\begin{array}{l}3.54(1.45 \\
8.65)\end{array}$ & $1.21(0.34,4.27)$ \\
\hline $\begin{array}{l}\text { HTN Requiring } \\
\text { Med }\end{array}$ & $\begin{array}{l}2693 \\
(51.3)\end{array}$ & 24 & $\begin{array}{l}2.55(1.18 \\
5.50)\end{array}$ & $1.70(0.58,4.94)$ \\
\hline Dialysis & $31(0.6)$ & 1 & $\begin{array}{l}5.41(0.72 \\
40.86)\end{array}$ & $\begin{array}{l}5.97(0.54 \\
66.38)\end{array}$ \\
\hline $\begin{array}{l}\text { Disseminated } \\
\text { Cancer }\end{array}$ & $319(6.1)$ & 4 & $\begin{array}{l}2.15(0.75 \\
6.15)\end{array}$ & $1.34(0.42,4.24)$ \\
\hline Weight Loss & 309 (5.9) & 6 & $\begin{array}{l}3.61(1.48, \\
8.80)\end{array}$ & $1.59(0.50,5.10)$ \\
\hline $\begin{array}{l}\text { Sodium } \\
\text { abnormality }\end{array}$ & $223(4.2)$ & 1 & $\begin{array}{l}0.48(0.06 \\
3.46)\end{array}$ & \\
\hline Creatinine $>1.2$ & $\begin{array}{l}575 \\
(13.0)\end{array}$ & 7 & $\begin{array}{l}1.87(0.71 \\
4.90)\end{array}$ & \\
\hline
\end{tabular}

Number in parenthesis is the percentage of total cases pertaining to that group and variable.

Chosen references are indicated by number 1 . For preoperative diagnoses, a chosen reference is not having the diagnosis ex. no diabetes, non-smoker, no dyspnea, etc. This is not reported on the table. For preoperative laboratory results, a chosen reference is the normal value of the laboratory test (serum sodium 135-145 mEg/L, creatinine $<1.2 \mathrm{mg} / \mathrm{dl}$, albumin $>3.5 \mathrm{~g} / \mathrm{dl}$, Total bilirubin $<1.2 \mathrm{mg} / \mathrm{dl}$, hematocrit $>30$, and INR < 1.2). Normal values are not reported in the table.

Covariates for the multivariable logistic regression analysis include all of those with a statistically significant OR.

Abbreviations: ASA, American Society of Anesthesiology; ACS NSQIP, American College of Surgeons National Surgical Quality Improvement Program; OR, Odds Ratio; Cl, Confidence Interval; SD, Standard Deviation; BMI, Body Mass Index; IDDM, Insulin Dependent Diabetes Mellitus; NIDDM, Non-Insulin Dependent Diabetes Mellitus; FHS, Functional Health Status; COPD, Chronic Obstructive Pulmonary Disease; Med, Medication; HTN, Hypertension; INR, International Normalized Ratio 


\begin{tabular}{|c|c|c|c|c|}
\hline Variable & $\mathbf{n}$ & $\begin{array}{l}\text { Postop death within } 30 \text { days } \\
\text { (\# of cases) }\end{array}$ & $\begin{array}{l}\text { Univariable } \\
\text { OR } \\
(95 \% \mathrm{Cl})\end{array}$ & $\begin{array}{l}\text { Multivariable } \\
\text { OR } \\
(95 \% \mathrm{Cl})\end{array}$ \\
\hline Albumin $<3.5$ & $\begin{array}{l}253 \\
(10.0)\end{array}$ & 8 & $\begin{array}{l}4.93(2.07 \\
11.75)\end{array}$ & $\begin{array}{l}3.76(1.35 \\
10.44)\end{array}$ \\
\hline $\begin{array}{l}\text { Total Bilirubin > } \\
1.2\end{array}$ & $119(5.2)$ & 1 & $\begin{array}{l}1.00(0.57 \\
1.73)\end{array}$ & \\
\hline Hematocrit $<30$ & $131(2.7)$ & 2 & $\begin{array}{l}0.92(0.86 \\
0.98)\end{array}$ & $0.99(0.91,1.08)$ \\
\hline INR $>1.2$ & $191(7.7)$ & 2 & $\begin{array}{l}1.16(0.15 \\
8.65)\end{array}$ & \\
\hline \multicolumn{5}{|l|}{$\begin{array}{l}\text { Hospital length } \\
\text { of stay }\end{array}$} \\
\hline Mean length (SD) & $4.7 \pm 4.6$ & & & \\
\hline $\begin{array}{l}\text { Length of stay }< \\
6 \text { days }\end{array}$ & $\begin{array}{l}4199 \\
(79.9)\end{array}$ & 15 & 1 & 1 \\
\hline $\begin{array}{l}\text { Length of stay } \geq \\
7 \text { days }\end{array}$ & $\begin{array}{l}1055 \\
(20.1)\end{array}$ & 18 & $\begin{array}{l}1.06(1.03, \\
1.09)\end{array}$ & $1.01(0.96,1.05)$ \\
\hline \multicolumn{5}{|c|}{ Number in parenthesis is the percentage of total cases pertaining to that group and variable. } \\
\hline \multicolumn{5}{|c|}{$\begin{array}{l}\text { Chosen references are indicated by number } 1 \text {. For preoperative diagnoses, a chosen reference is not } \\
\text { having the diagnosis ex. no diabetes, non-smoker, no dyspnea, etc. This is not reported on the table. } \\
\text { For preoperative laboratory results, a chosen reference is the normal value of the laboratory test } \\
\text { (serum sodium } 135-145 \mathrm{mEq} / \mathrm{L} \text {, creatinine }<1.2 \mathrm{mg} / \mathrm{dl} \text {, albumin }>3.5 \mathrm{~g} / \mathrm{dl} \text {, Total bilirubin }<1.2 \mathrm{mg} / \mathrm{dl} \text {, } \\
\text { hematocrit }>30 \text {, and INR }<1.2 \text { ). Normal values are not reported in the table. }\end{array}$} \\
\hline \multicolumn{5}{|c|}{$\begin{array}{l}\text { Covariates for the multivariable logistic regression analysis include all of those with a statistically } \\
\text { significant OR. }\end{array}$} \\
\hline \multicolumn{5}{|c|}{$\begin{array}{l}\text { Abbreviations: ASA, American Society of Anesthesiology; ACS NSQIP, American College of Surgeons } \\
\text { National Surgical Quality Improvement Program; OR, Odds Ratio; CI, Confidence Interval; SD, Standard } \\
\text { Deviation; BMI, Body Mass Index; IDDM, Insulin Dependent Diabetes Mellitus; NIDDM, Non-Insulin } \\
\text { Dependent Diabetes Mellitus; FHS, Functional Health Status; COPD, Chronic Obstructive Pulmonary } \\
\text { Disease; Med, Medication; HTN, Hypertension; INR, International Normalized Ratio }\end{array}$} \\
\hline ** BMI was not rec & rded for $9 \mathrm{p}$ & ients & & \\
\hline
\end{tabular}


Table 2

Percentage of Cases for each Surgical Specialty Reported to have postoperative mortality.

\begin{tabular}{|c|c|c|}
\hline Surgical Specialty & Number of patients & $\begin{array}{l}\text { Postoperative death within } \\
30 \text { days } n(\%)\end{array}$ \\
\hline General & 3270 & $23(0.7)$ \\
\hline Urology & 1185 & $2(0.2)$ \\
\hline Vascular & 306 & $4(1.3)$ \\
\hline Thoracic & 247 & $3(1.2)$ \\
\hline Plastic & 212 & 0 \\
\hline Otolaryngology & 34 & $1(2.9)$ \\
\hline $\begin{array}{l}\text { Demographic } \\
\text { information }\end{array}$ & Preoperative Diagnoses & Postoperative complications \\
\hline Age & Diabetes status & Hospital length of stay \\
\hline Gender & IDDM & $\begin{array}{l}\text { Hospital discharge } \\
\text { destination }\end{array}$ \\
\hline Procedure duration & NIDDM & Home \\
\hline $\begin{array}{l}\text { ASAPS } \\
\text { classification }\end{array}$ & Smoking status & $\begin{array}{l}\text { Rehab/Skilled Care/Other } \\
\text { Facility }\end{array}$ \\
\hline \multirow[t]{3}{*}{ Body Mass Index } & Dyspnea & Expired \\
\hline & Dyspnea at rest & Unknown \\
\hline & Dyspnea with moderate exertion & $\begin{array}{l}\text { Postoperative death within } \\
30 \text { days }\end{array}$ \\
\hline $\begin{array}{l}\text { Preoperative } \\
\text { laboratory results }\end{array}$ & Functional Health Status & $\begin{array}{l}\text { Readmission within } 30 \text { days } \\
\text { of discharge }\end{array}$ \\
\hline Serum sodium & Independent & Unplanned readmission \\
\hline Creatinine & Partially & $\begin{array}{l}\text { Related to principal } \\
\text { procedure }\end{array}$ \\
\hline Albumin & Totally dependent & Unplanned return to the OR \\
\hline Total bilirubin & Ventilator dependent & $\begin{array}{l}\text { Related to principal } \\
\text { procedure }\end{array}$ \\
\hline Hematocrit & Chronic obstructive pulmonary disease & $\begin{array}{l}\text { More than } 2 \text { unplanned } \\
\text { returns to the OR }\end{array}$ \\
\hline
\end{tabular}

Percentages were calculated from the total cases from each individual specialty.

Supplementary table 1. NSQIP extracted list of variables included in the analysis 


\begin{tabular}{|c|c|c|}
\hline Surgical Specialty & Number of patients & $\begin{array}{l}\text { Postoperative death within } \\
30 \text { days } n(\%)\end{array}$ \\
\hline Platelet count & Ascites* & \\
\hline \multirow[t]{2}{*}{ INR } & Congestive heart failure & \\
\hline & Hypertension requiring medication & \\
\hline Other & Dialysis & \\
\hline CPT codes & Disseminated cancer & \\
\hline ICD-9 codes & Steroid immunosuppressant use & \\
\hline \multirow[t]{7}{*}{ Surgical specialty } & Bleeding disorder & \\
\hline & Acute renal failure* & \\
\hline & $\begin{array}{l}\text { More than } 10 \% \text { body weight loss in the prior } \\
6 \text { months to surgery }\end{array}$ & \\
\hline & $\begin{array}{l}\text { Transfusion of red blood cells } 72 \text { hours prior } \\
\text { to surgery }\end{array}$ & \\
\hline & Systemic inflammatory response syndrome & \\
\hline & Sepsis & \\
\hline & Septic shock* & \\
\hline \multicolumn{3}{|c|}{ *There were no cases of acute renal failure, septic shock, and ascites in the extracted data. } \\
\hline \multicolumn{3}{|c|}{$\begin{array}{l}\text { Abbreviations: ASA-PS, American Society of Anesthesiologists physical status; IDDM, insulin } \\
\text { dependent diabetes mellitus; NIDDM, non-insulin dependent diabetes mellitus; INR, International } \\
\text { normalized ratio; CPT, Current Procedural Terminology; ICD-9, International Classification of Diseases } \\
\text { ninth revision; OR, Operating room. }\end{array}$} \\
\hline \multicolumn{3}{|c|}{ Percentages were calculated from the total cases from each individual specialty. } \\
\hline Supplementary tab & NSQIP extracted list of variables included in th & Inalysis \\
\hline
\end{tabular}

\section{Discussion}

In a comprehensive analysis of the ACS NSQIP ${ }^{\circledR}$ database, spreading across multiple surgical specialties, we found that a higher ASA PS, less than normal preoperative albumin levels and impaired preoperative functional capacity were associated with 30-day mortality in patients undergoing elective non-cardiac surgery. Despite significant advances in perioperative care, postoperative mortality remains high and although the ACS NSQIP ${ }^{\circledR}$ SRC provides an estimate of this risk, identification of specific risk factors is essential to implement targeted interventions and our analysis is such an attempt. 
We identified less than normal preoperative serum albumin levels to be a significant predictor of postoperative mortality. Although serum albumin levels can be impacted by a multitude of conditions, in patients undergoing elective surgery, these could be considered surrogate markers of preoperative nutritional status. Low preoperative serum albumin levels have been found to be associated with significant risk of postoperative complications including poor wound healing, surgical site infections and mortality in various surgical populations.(9-11) However, most of these studies included both elective and emergency surgeries, or were confined to a sample involving specific pathologies and surgical procedures. In a large prospective observational study spread across forty-four tertiary care veterans affairs (VA) medical centers more than a decade ago, the authors concluded that serum albumin concentration is a better predictor of surgical outcomes than many other preoperative patient characteristics.(12) Despite awareness of the association of a low preoperative albumin with worse outcomes, over $10 \%$ of the patients in our cohort had less than normal albumin values prior to surgery.

Although the relationship of hypoalbuminemia and poor surgical outcome has been known for many years, the pathophysiology behind the relationship is unclear. Hypoalbuminemia may be an indicator of poor nutritional status, and hence contribute towards poor postoperative outcomes. Secondly, since albumin has antioxidant and carrier properties, a lack or deficiency thereof, might result in inadequate performance of these tasks, thus further pre-disposing to postoperative complications. Thirdly, since albumin is a known negative acute phase protein, hypoalbuminemia might represent a pre-existing amplified inflammatory status of the patient. Kim et al(13) reviewed this relationship in detail, explored the fallacies with these hypothesis and concluded that Interventions designed solely to correct preoperative hypoalbuminemia, in particular intravenous albumin infusion, do little to change the patient's course of hospitalization. In essence, it is the optimization of preoperative nutritional status that is important and whether elective surgery should be delayed until nutritional status has been optimized and preoperative serum albumin levels are normalized needs to be explored in future studies. A direct relationship between improvement in nutritional status and correction of serum albumin values has yet to be established.

Impaired preoperative FHS was another factor that was associated with a higher likelihood of postoperative mortality in our cohort. Functional health status is often defined as one's ability to perform daily activities required to meet basic needs, fulfill usual roles, and maintain their health and well-being. (14) For documentation into the NSQIP database, patient charts are manually reviewed to determine the level of patient's functional health status. Patients are placed into one of three categories: independent, partially dependent, and totally dependent. An independent patient is defined as one who does not require assistance from another person for any activities of daily living. A partially dependent patient requires some assistance from another person for activities of daily living regardless of use of prosthetics, equipment, and/or devices. Finally, a totally dependent patient requires total assistance for all activities of daily living. The best functional status demonstrated by the patient, within the 30 days prior to the principal operative procedure or at the time the patient is being considered a candidate for surgery is recorded. 
Functional health status has been identified as a major risk factor for postoperative complications in isolated surgical cohorts $(15,16)$ and as part of the preoperative mortality predictor (PMP) in patients undergoing major abdominal surgery.(17) However, its association with mortality across all surgical procedures has not been explored before. Patients with poor functional capacity are generally sicker, tend to have more comorbidities, and may present later in their disease process, which may result in higher mortality. The decision to operate on patients with poor FHS should be thoroughly reviewed with a detailed preoperative workup and in patients in whom surgery is indicated, optimization pathways should be implemented. Functional health status is also an important determinant of preoperative cardiovascular non-invasive testing and forms an integral part of the American College of Cardiology (ACC)/American Heart Association (AHA) guidelines on perioperative cardiovascular evaluation and management of patients undergoing elective non-cardiac surgery.(18)

Improvement of FHS prior to elective surgery can be beneficial and pre-habilitation prior to major abdominal surgery was recently found to reduce overall and pulmonary morbidity.(19) However, in a systematic review of the impact of pre-habilitation programs in abdominal cancer surgery, no significant difference between patients undergoing pre-habilitation and standard care groups were observed.(20) There seems to be heterogeneity in the composition, mode of administration and the outcome measures of functional capacity that are used to evaluate the impact of pre-habilitation programs that may account for these incongruent findings.

The ASA Classification System, introduced in 1941, is routinely assigned to patients prior to procedures where an anesthesia professional is present, and application of this system has become a standard component of anesthetic practice worldwide. We found that a higher ASA physical status was associated with postoperative mortality and prior studies have also reported similar association.(21) Although, the ASA classification system is associated with inter-observer variability and can be inconsistent, it does demonstrate validity as a marker of patients' preoperative health status. $(22,23)$

We believe that the strength of this study is the inclusion of a diverse population of patients who underwent varied surgical procedures. However, there are a few limitations. Our analysis is limited by our observed low mortality rate of $0.6 \%$, likely due to the heterogeneity of surgical cases reported in the NSQIP database. Further, NSQIP audited cases are chosen randomly, and thus may not be reflective of the overall surgical case mix. In addition, the lack of reporting of intraoperative complications in the NSQIP database makes the evaluation of valuable data such as blood loss, transfusions, and anesthesia type, unfeasible. Also, the NSQIP database fails to report important clinical risk factors, such as frailty. The retrospective nature and analysis of surgical cases from a single center also limit the generalizability of our findings.

\section{Conclusion}

In conclusion, our comprehensive analysis of the ACS NSQIPOे database identified preoperative functional health status, low serum albumin, and a high ASA physical status as significant predictors of 30-day

Page $12 / 18$ 
mortality in patients undergoing elective non-cardiac surgeries. Optimization of nutritional and functional status prior to surgery and including preoperative nutrition counselling and pre-habilitation programs to early recovery after surgery (ERAS) pathways may help decrease the impact of these modifiable variables on postoperative outcomes. Further studies are required to assess that impact.

\section{Abbreviations}

ACS NSQIPÒ American College of Surgeons National Surgical Quality Improvement Program

SRC surgical risk calculator

ASA American Society of Anesthesiologists

BMI body mass index

SD standard deviations

OR odds ratio

$\mathrm{Cl}$ confidence interval

VA veterans affairs

PMP preoperative mortality predictor

ACC American College of Cardiology

AHA American Heart Association

ERAS early recovery after surgery

\section{Declarations}

Ethics approval and consent to participate: The study was approved by the Penn State College of Medicine Institutional Review Board (Study no: 7024, approval date: 03/28/2017 and a waiver for patient consent was granted.

Consent for publication: Not applicable

Availability of data and materials: The datasets used and/or analyzed during the current study are available from the corresponding author on reasonable request.

Competing interests: The authors declare that they have no competing interests 
Funding: This research did not receive any specific grant from funding agencies in the public, commercial, or not-for-profit sectors.

Authors' contributions:

All authors have read and approved the manuscript.

AKM Analyzed the data and wrote the initial draft as well as edited the manuscript.

MB Collected and analyzed the data and edited the manuscript.

PMS Analyzed the data and edited the manuscript

AB Analyzed the data and edited the manuscript

KK Conceptualized the study, collected and analyzed the data and edited the manuscript.

Acknowledgements: Not Applicable

\section{References}

1. Gabriel RA, Sztain JF, A'Court AM, Hylton DJ, Waterman RS, Schmidt U. Postoperative mortality and morbidity following non-cardiac surgery in a healthy patient population. J Anesth. 2018;32(1):112-9.

2. Eamer G, Al-Amoodi MJH, Holroyd-Leduc J, Rolfson DB, Warkentin LM, Khadaroo RG. Review of risk assessment tools to predict morbidity and mortality in elderly surgical patients. Am J Surg. 2018;216(3):585-94.

3. ACS National Surgical Quality Improvement Program ${ }^{\circledR}$ (ACS NSQIP®). Home Page on the internet [Available from: https://www.facs.org/quality-programs/acs-nsqip.

4. Ingraham AM, Richards KE, Hall BL, Ko CY. Quality improvement in surgery: the American College of Surgeons National Surgical Quality Improvement Program approach. Adv Surg. 2010;44:251-67.

5. Bilimoria KY, Liu Y, Paruch JL, Zhou L, Kmiecik TE, Ko CY, et al. Development and evaluation of the universal ACS NSQIP surgical risk calculator: a decision aid and informed consent tool for patients and surgeons. J Am Coll Surg. 2013;217(5):833-42. e1-3.

6. O'Neill AC, Bagher S, Barandun M, Hofer SO, Zhong T. Can the American College of Surgeons NSQIP surgical risk calculator identify patients at risk of complications following microsurgical breast reconstruction? J Plast Reconstr Aesthet Surg. 2016;69(10):1356-62.

7. Prasad KG, Nelson BG, Deig CR, Schneider AL, Moore MG. ACS NSQIP Risk Calculator: An Accurate Predictor of Complications in Major Head and Neck Surgery? Otolaryngol Head Neck Surg. 2016;155(5):740-2.

8. Bruceta M, De Souza L, Carr ZJ, Bonavia A, Kunselman AR, Karamchandani K. Post-operative intensive care unit admission after elective non-cardiac surgery: A single-center analysis of the NSQIP database. Acta Anaesthesiol Scand. 2020;64(3):319-28. 
9. Adogwa O, Martin JR, Huang K, Verla T, Fatemi P, Thompson P, et al. Preoperative serum albumin level as a predictor of postoperative complication after spine fusion. Spine (Phila Pa 1976). 2014;39(18):1513-9.

10. Nguyen GC, Du L, Chong RY, Jackson TD. Hypoalbuminaemia and Postoperative Outcomes in Inflammatory Bowel Disease: the NSQIP Surgical Cohort. J Crohns Colitis. 2019;13(11):1433-8.

11. Garg T, Chen LY, Kim PH, Zhao PT, Herr HW, Donat SM. Preoperative serum albumin is associated with mortality and complications after radical cystectomy. BJU Int. 2014;113(6):918-23.

12. Gibbs J, Cull W, Henderson W, Daley J, Hur K, Khuri SF. Preoperative serum albumin level as a predictor of operative mortality and morbidity: results from the National VA Surgical Risk Study. Arch Surg. 1999;134(1):36-42.

13. Kim S, McClave SA, Martindale RG, Miller KR, Hurt RT. Hypoalbuminemia and Clinical Outcomes: What is the Mechanism behind the Relationship? Am Surg. 2017;83(11):1220-7.

14. Wilson IB, Cleary PD. Linking clinical variables with health-related quality of life. A conceptual model of patient outcomes. JAMA. 1995;273(1):59-65.

15. Albright EL, Davenport DL, Roth JS. Preoperative functional health status impacts outcomes after ventral hernia repair. Am Surg. 2012;78(2):230-4.

16. Curtis GL, Hammad A, Anis HK, Higuera CA, Little BE, Darwiche HF. Dependent Functional Status is a Risk Factor for Perioperative and Postoperative Complications After Total Hip Arthroplasty. J Arthroplasty. 2019;34(7S):348-S51.

17. Vaid S, Bell T, Grim R, Ahuja V. Predicting risk of death in general surgery patients on the basis of preoperative variables using American College of Surgeons National Surgical Quality Improvement Program data. Perm J. 2012;16(4):10-7.

18. Fleisher LA, Fleischmann KE, Auerbach AD, Barnason SA, Beckman JA, Bozkurt B, et al. 2014 ACC/AHA guideline on perioperative cardiovascular evaluation and management of patients undergoing noncardiac surgery: executive summary: a report of the American College of Cardiology/American Heart Association Task Force on practice guidelines. Developed in collaboration with the American College of Surgeons, American Society of Anesthesiologists, American Society of Echocardiography, American Society of Nuclear Cardiology, Heart Rhythm Society, Society for Cardiovascular Angiography and Interventions, Society of Cardiovascular Anesthesiologists, and Society of Vascular Medicine Endorsed by the Society of Hospital Medicine. J Nucl Cardiol. 2015;22(1):162-215.

19. Hughes MJ, Hackney RJ, Lamb PJ, Wigmore SJ, Christopher Deans DA, Skipworth RJE. Prehabilitation Before Major Abdominal Surgery: A Systematic Review and Meta-analysis. World J Surg. 2019;43(7):1661-8.

20. Hijazi Y, Gondal U, Aziz O. A systematic review of prehabilitation programs in abdominal cancer surgery. Int J Surg. 2017;39:156-62.

21. Davenport DL, Bowe EA, Henderson WG, Khuri SF, Mentzer RM. Jr. National Surgical Quality Improvement Program (NSQIP) risk factors can be used to validate American Society of 
Anesthesiologists Physical Status Classification (ASA PS) levels. Ann Surg. 2006;243(5):636-41. discussion $41-4$.

22. Cuvillon P, Nouvellon E, Marret E, Albaladejo P, Fortier LP, Fabbro-Perray P, et al. American Society of Anesthesiologists' physical status system: a multicentre Francophone study to analyse reasons for classification disagreement. Eur J Anaesthesiol. 2011;28(10):742-7.

23. Sankar A, Johnson SR, Beattie WS, Tait G, Wijeysundera DN. Reliability of the American Society of Anesthesiologists physical status scale in clinical practice. Br J Anaesth. 2014;113(3):424-32.

\section{Supplementary Table}

Supplementary table 1. NSQIP extracted list of variables included in the analysis 


\begin{tabular}{|c|c|c|}
\hline $\begin{array}{l}\text { Demographic } \\
\text { information }\end{array}$ & Preoperative Diagnoses & Postoperative complications \\
\hline Age & Diabetes status & Hospital length of stay \\
\hline Gender & IDDM & Hospital discharge destination \\
\hline Procedure duration & NIDDM & Home \\
\hline ASAPS classification & Smoking status & $\begin{array}{l}\text { Rehab/Skilled Care/Other } \\
\text { Facility }\end{array}$ \\
\hline \multirow[t]{3}{*}{ Body Mass Index } & Dyspnea & Expired \\
\hline & Dyspnea at rest & Unknown \\
\hline & Dyspnea with moderate exertion & $\begin{array}{l}\text { Postoperative death within } 30 \\
\text { days }\end{array}$ \\
\hline $\begin{array}{l}\text { Preoperative laboratory } \\
\text { results }\end{array}$ & Functional Health Status & $\begin{array}{l}\text { Readmission within } 30 \text { days of } \\
\text { discharge }\end{array}$ \\
\hline Serum sodium & Independent & Unplanned readmission \\
\hline Creatinine & Partially & Related to principal procedure \\
\hline Albumin & Totally dependent & Unplanned return to the OR \\
\hline Total bilirubin & Ventilator dependent & Related to principal procedure \\
\hline Hematocrit & Chronic obstructive pulmonary disease & $\begin{array}{l}\text { More than } 2 \text { unplanned returns } \\
\text { to the OR }\end{array}$ \\
\hline Platelet count & Ascites* & \\
\hline \multirow[t]{2}{*}{ INR } & Congestive heart failure & \\
\hline & Hypertension requiring medication & \\
\hline Other & Dialysis & \\
\hline CPT codes & Disseminated cancer & \\
\hline ICD-9 codes & Steroid immunosuppressant use & \\
\hline \multirow[t]{7}{*}{ Surgical specialty } & Bleeding disorder & \\
\hline & Acute renal failure* & \\
\hline & $\begin{array}{l}\text { More than } 10 \% \text { body weight loss in the prior } 6 \\
\text { months to surgery }\end{array}$ & \\
\hline & $\begin{array}{l}\text { Transfusion of red blood cells } 72 \text { hours prior to } \\
\text { surgery }\end{array}$ & \\
\hline & Systemic inflammatory response syndrome & \\
\hline & Sepsis & \\
\hline & Septic shock* & \\
\hline
\end{tabular}

*There were no cases of acute renal failure, septic shock, and ascites in the extracted data.

Abbreviations: ASA-PS, American Society of Anesthesiologists physical status; IDDM, insulin dependent diabetes mellitus; NIDDM, non-insulin dependent diabetes mellitus; INR, International normalized ratio; CPT, Current 
Procedural Terminology; ICD-9, International Classification of Diseases ninth revision; OR, Operating room. 